Article

\title{
Assessment of the Suitability of the One-Step Hydrothermal Method for Preparation of Non-Covalently/Covalently-Bonded $\mathrm{TiO}_{2} /$ Graphene-Based Hybrids
}

\author{
Ewelina Kusiak-Nejman * (D), Dariusz Moszyński, Joanna Kapica-Kozar, Agnieszka Wanag and \\ Antoni W. Morawski \\ Institute of Inorganic Technology and Environment Engineering, Faculty of Chemical Engineering, \\ West Pomeranian University of Technology, Szczecin, Pułaskiego 10, 70-322 Szczecin, Poland; \\ Dariusz.Moszynski@zut.edu.pl (D.M.); Joanna.Kapica@zut.edu.pl (J.K.-K.); \\ Agnieszka.Wanag@zut.edu.pl (A.W.); amor@zut.edu.pl (A.W.M.) \\ * Correspondence: ekusiak@zut.edu.pl; Tel.: +48-91-449-6045
}

Received: 19 July 2018; Accepted: 21 August 2018; Published: 23 August 2018

\begin{abstract}
A hybrid nanocomposites containing nanocrystalline $\mathrm{TiO}_{2}$ and graphene-related materials (graphene oxide or reduced graphene oxide) were successfully prepared by mechanical mixing and the hydrothermal method in the high-pressure atmosphere. The presented X-ray photoelectron spectroscopy (XPS) study and quantitative elemental analysis confirm similar content of carbon in graphene oxide GO (52 $\mathrm{wt} \%$ and $46 \mathrm{wt} \%$, respectively) and reduced graphene oxide $\mathrm{rGO}(92 \mathrm{wt} \%$ and $98 \mathrm{wt} \%$, respectively). No chemical interactions between $\mathrm{TiO}_{2}$ and $\mathrm{GO} / \mathrm{rGO}$ was found. $\mathrm{TiO}_{2}$ nanoparticles were loaded on $\mathrm{GO}$ or rGO flakes. However, Fourier transform infrared-diffuse reflection spectroscopy (FTIR/DRS) allowed finding peaks characteristic of GO and rGO. XPS study shows that since the concentration of $\mathrm{TiO}_{2}$ in the samples was no less than $95 \mathrm{wt} \%$, it was assumed that the interactions between $\mathrm{TiO}_{2}$ and graphene should not influence the lower layers of titanium atoms in the $\mathrm{TiO}_{2}$ and they occurred as $\mathrm{Ti}^{4+}$ ions. Hydrothermal treatment at $200^{\circ} \mathrm{C}$ did not cause the reduction of $\mathrm{GO}$ to $\mathrm{rGO}$ in $\mathrm{TiO}_{2}-\mathrm{GO}$ nanocomposites. In general, the one-step hydrothermal method must be considered to be inefficient for preparation of chemically-bonded composites synthesized from commercially available $\mathrm{TiO}_{2}$ and unfunctionalized graphene sheets obtained from graphite powder.
\end{abstract}

Keywords: $\mathrm{TiO}_{2}$; graphene; hybrid composites; hydrothermal method; $\mathrm{TiO}_{2}$-graphene bonding

\section{Introduction}

In the last decade, the preparation and application of semiconductor nanomaterials and graphene nanocomposites have been intensively studied [1-5]. In the context of water and air purification, particular attention is being paid to $\mathrm{TiO}_{2}$-graphene hybrid nanomaterials [5-11]. These $\mathrm{TiO}_{2}$-reduced graphene oxide $\left(\mathrm{TiO}_{2}\right.$-rGO) and $\mathrm{TiO}_{2}$-graphene oxide $\left(\mathrm{TiO}_{2}\right.$-GO) nanocomposites have been synthesized with various methods $[3,5]$ i.e., solution mixing methods, sonication-assisted mixing, sol-gel process, hydrothermal/solvothermal synthesis, self-assembly, microwave-assisted methods, direct electrochemical deposition, liquid-phase or chemical vapour deposition.

Hydrothermal/solvothermal synthesis is commonly utilized as simple route to obtain titania-graphene hybrids. The main advantages of this process are possibility of $\mathrm{TiO}_{2}$ phase transformation, thermal reduction of graphene oxide to graphene (rGO), and preparation of hybrid nanocomposites with unique morphologies without post-synthetic annealing $[5,12,13]$. In general, preparation of $\mathrm{TiO}_{2}$-graphene hybrids can occur as one- or two-step hydrothermal treatment 
depending on whether commercially available $\mathrm{TiO}_{2}$ or titanium precursors is utilized. One-pot hydrothermal synthesis is commonly running with utilization of commercially available $\mathrm{TiO}_{2}$ and previously-prepared graphene-based materials [9,11,14-18]. Although the one-step synthesis of graphene-modified titania hybrids have also been conducted using titanium precursor [19-21], the two-step hydrothermal process is usually preceded by synthesis of titania from various titanium compounds [10,21-26].

Covalently-bonded hybrids are considered to be the most chemically stable composites. According to Bai et al. [26] the presence of strong chemical interactions through formation of $\mathrm{Ti}-\mathrm{O}-\mathrm{C}$ was possible due to preparation of $\mathrm{TiO}_{2}$-graphene hybrids from $\mathrm{TiF}_{4}$ precursor. The hydrolysis process was conducted in the presence of graphene flakes. Hydrothermal treatment was conducted to reduce GO to rGO. The appearance of $\mathrm{Ti}-\mathrm{O}-\mathrm{C}$ and Ti-C bonds was proved by means of FTIR/DRS, XPS and X-ray powder diffraction (XRD) analyses. These bonds were formed during reduction of oxygen-containing functional groups on $\mathrm{GO}$ edge. Liang et al. [19] synthesized $\mathrm{TiO}_{2}-\mathrm{rGO}$ composites conducting hydrothermal hydrolysis of $\mathrm{Ti}\left(\mathrm{SO}_{4}\right)_{2}$ and GO. The presence of $\mathrm{Ti}-\mathrm{O}-\mathrm{C}$ bonds was proven by the slight red-shift of the light absorption. FTIR/DRS analysis did not confirm the formation of chemical bonds between $\mathrm{TiO}_{2}$ and rGO. Shi et al. [21], contrary to two previous papers, confirm the non-covalent interactions in tested nanocomposites (by XPS, FTIR/DRS, and UV-VIS/DRS methods). However, in this case tertbutyl titanate and dextran were used as the $\mathrm{TiO}_{2}$ precursor and $\mathrm{GO}$ reduction medium, respectively. The reduction of GO, firstly with dextran, and then by hydrothermal treatment, was confirmed by FTIR/DRS spectroscopy.

In this work we would like to show whether preparation of chemically bonded $\mathrm{TiO}_{2}$-graphene materials could have been achieved with one-step hydrothermal method, utilizing commercial titania and GO or rGO sheets. Zhang et al. [14] prepared chemically-bonded $\mathrm{TiO}_{2} \mathrm{P} 25-\mathrm{rGO}$ composite as a result of hydrothermal treatment of P25 and GO at $120{ }^{\circ} \mathrm{C}$ for $3 \mathrm{~h}$. Ti-O-C bonds were formed during the thermal reduction of residual $-\mathrm{COOH}$ edge functional groups reacting with $-\mathrm{OH}$ groups on the surface of P25. The titania particles were mainly concentrated in the edge of graphene flakes. The chemical interactions were confirmed on the basis of FTIR/DRS analysis (suggested presence of Ti-O-C) and UV-VIS/DRS (slight bathochromic shift). Similar results were obtained by Li et al. [17]: preparation of $\mathrm{P} 25-\mathrm{rGO}$ at $120^{\circ} \mathrm{C}$ for $3 \mathrm{~h}$ led to formation of chemical bonds between titania and rGO sheets during the reduction of carbon- and oxygen-containing edge functional groups of GO (confirmed by the red-shift of absorption edge). However, titania nanoparticles were located on the whole surface of graphene matrix. In contrast, Qianqian et al. [15] explained that no covalent-bonding hybrids can be prepared from commercial P25 and GO during the hydrothermal process. Titania nanotubes were loaded on the flakes of rGO (prepared from thermal reduction of GO). The slight narrowing of the band gap was related to the presence of impurities that could shift the absorption edge.

The purpose of this paper is to discuss the impact of preparation methods (mechanical mixing and hydrothermal treatment) as well as utilization of different types of graphene-related materials (GO or $\mathrm{rGO}$ ) with various mass ratios on the structural and textural properties of hybrid nanocomposites. On the basis of obtained results the assessment of the one-pot hydrothermal method suitability for preparation of chemically-bonded hybrids form commercial $\mathrm{TiO}_{2}$ and graphene-related materials has been performed. In general, formation of covalent bonds between $\mathrm{TiO}_{2}$ and graphene-based materials is more likely to occur during hydrolysis and synthesis of $\mathrm{TiO}_{2}$ from precursor compounds then from commercially available titania with strictly-defined morphology.

\section{Experimental}

\subsection{Materials and Reagents}

The titanium dioxide slurry supplied by sulphate technology from Chemical Plant Grupa Azoty Zakłady Chemiczne "POLICE" S.A. (Police, Poland) was used as a bare $\mathrm{TiO}_{2}$ for preparation of new hybrids. Before modification the crude $\mathrm{TiO}_{2}$ has been pre-treated as described in our previous 
work [27]. Graphene materials (graphene oxide GO and reduced graphene oxide rGO) synthesized by modified Hummer's method, were supplied by Institute of Electronic Materials Technology (Warsaw, Poland) [28]. Firstly, the appropriate amount of GO was prepared. Then, the amount of GO was divided into equal halves and one of obtained halves was reduced to obtain reduced graphene oxide. In other words, reduced graphene oxide was obtained from the same part of graphene oxide. High purity water (Millipore Elix Advantage water purification system purchased from Merck KGaA, Darmstadt, Germany, with the conductivity of $0.05 \mu \mathrm{S} / \mathrm{cm}$ at $25{ }^{\circ} \mathrm{C}$ ) and primary aliphatic alcohol 1-butanol (purity 99\%, Avantor Performance Materials Poland S.A., Gliwice, Poland) were used in order to improve the contact between titania nanoparticles and graphene sheets. $\mathrm{BaSO}_{4}$ (purchased from Avantor Performance Materials Poland S.A., Gliwice, Poland, purity 98\%) was used as a reference material in light absorption analysis.

\subsection{Characterization Methods}

The crystalline structure and relative phase composition of obtained materials were characterized by X-ray powder diffraction (XRD) analysis (Empyrean, Malvern Panalytical Ltd., Malvern, UK) using $\mathrm{Cu} \mathrm{K} \alpha$ radiation $(\lambda=1.54056 \AA)$. The diffractometer was equipped with a wide-angle detector (PIXcel 3D) and a monochromator, which greatly lowers the signal to noise ratio. The measurements were made in the range of $10-80^{\circ}$ in $2 \theta$ scale. The PDF-4+ 2014 International Centre for Diffraction Data database was used for the determination of the phase composition. The average anatase crystallite diameter $d_{A}(\mathrm{~nm})$ was calculated according to Scherrer's equation. The morphology of the GO and rGO flakes, as well as the obtained selected nanocomposites, was observed by scanning electron microscopy (SEM) utilizing a Hitachi SU8020 ultra-high resolution field emission scanning electron microscope (Hitachi Ltd., Tokyo, Japan).

The Brunauer-Emmett-Teller surface area $\left(S_{B E T}\right)$ of the obtained photocatalysts was determined on the basis of nitrogen adsorption-desorption measurements at $77 \mathrm{~K}$ conducted in Quadrasorb SI (Quantachrome, Boynton Beach, FL, USA) equipment. Prior to analysis, each sample was degassed at $105{ }^{\circ} \mathrm{C}$ for $12 \mathrm{~h}$ under high vacuum. The pore volume distributions as a function of pore size were calculated based on the Dubinin-Radushkevich equation using adsorption branches of the measured isotherm. The quantitative analysis of carbon content in $\mathrm{GO}, \mathrm{rGO}$, and $\mathrm{TiO}_{2}-\mathrm{GO}$ and $\mathrm{TiO}_{2}-\mathrm{rGO}$ samples were determined by means of a CN628 elemental analyser (LECO Corporation, Saint Joseph, MI, USA). The certified BBOT standard (LECO Corporation, Saint Joseph, MI, USA) containing $72.62 \mathrm{wt} \%$ of carbon, $7.35 \mathrm{wt} \%$ of sulphur, $6.37 \mathrm{wt} \%$ of nitrogen, and $6.12 \mathrm{wt} \%$ of hydrogen was utilized for a calibration curve for calculation of carbon concentration in GO and rGO samples. The certified EDTA standard (LECO Corporation, Saint Joseph, MI, USA) containing $41.06 \mathrm{wt} \%$ of carbon and $9.56 \mathrm{wt} \%$ of nitrogen was used for preparation of a calibration curve for calculation of carbon concentration in hybrid nanocomposites.

A 4200 Fourier transform infrared-diffuse reflection (FTIR/DRS) spectrophotometer (Jasco Co., Tokyo, Japan) equipped with diffuse reflectance accessory from the Harrick Scientific Products Inc. (Pleasantville, NY, USA) was used to characterize the $\mathrm{TiO}_{2}$ after modification with GO, $\mathrm{rGO}$ and/or a different liquid medium.

The X-ray photoelectron experiments were performed using $\mathrm{Al} \mathrm{K} \alpha(\mathrm{hv}=1486.6 \mathrm{eV})$ radiation with a Scienta SES 2002 spectrometer (Scienta Scientific AB, Uppsala, Sweden) operating at constant transmission energy $\left(\mathrm{E}_{\mathrm{p}}=50 \mathrm{eV}\right)$. The spectrometer was calibrated according to the photoemission line $\mathrm{Ag} 3 \mathrm{~d}_{5 / 2} \mathrm{E}_{\mathrm{B}}=368.3 \mathrm{eV}$. The powder samples were loosely placed into the sample holder. The analysis chamber during experiments was evacuated to better than $1 \times 10^{-9}$ mbar. Due to the charging effects observed in the obtained experimental spectra a binding energy scale had to be corrected for most of the experiments. Since all samples contained complex carbon species the adventitious carbon usually taken as a reference in XPS experiments could not be used. Since all samples contained complex carbon species the adventitious carbon usually taken as a reference in XPS experiments could not be used. The mean free path of photoelectrons in $\mathrm{TiO}_{2}$ is about $2 \mathrm{~nm}$ [29]. Therefore, a majority of the 
XPS signal of Ti $2 p$ electrons originates in the second and lower layers from the surface. Since the concentration of titanium oxide in the samples was no less than $95 \mathrm{wt} \%$, it was assumed that the interactions between $\mathrm{TiO}_{2}$ and graphene should not influence the lower layers of titanium atoms in the $\mathrm{TiO}_{2}$ and they occurred as $\mathrm{Ti}^{4+}$ ions. Regarding this, the position of the maximum of XPS Ti $2 \mathrm{p}_{3 / 2}$ line was taken as a reference position and the binding energy scale of other XPS lines acquired in the experiments were corrected accordingly. The position of XPS Ti $2 \mathrm{p}_{3 / 2}$ was arbitrarily set at $459.0 \mathrm{eV}$ since previous reports indicated a range between $458.5 \mathrm{eV}$ and $459.2 \mathrm{eV}$ [30-32].

The light absorption abilities of the samples were obtained by UV-VIS-diffuse reflection spectroscopy (UV-VIS/DRS) by means of V-650 UV-VIS spectrophotometer (Jasco Co., Tokyo, Japan) equipped with an integrating sphere accessory for studying DR spectra. Barium sulphate (purity $98 \%$, Avantor Performance Materials, Gliwice, Poland) was used as a reference material.

All the experiments were conducted with special reference to the paper by Rogala et al. [33] discussing the influence of standard measurements on chemical and electronic structure of graphene.

\subsection{Preparation of $\mathrm{TiO}_{2}-\mathrm{GO}$ and $\mathrm{TiO}_{2}-r \mathrm{GO}$ Nanocomposites}

The tested hybrid nanocomposites were prepared in two ways: simple mechanical mixing of starting $\mathrm{TiO}_{2}(4 \mathrm{~g})$ with 1 or $5 \mathrm{wt} \%$ of GO or rGO flakes in the agate mortar and under elevated pressure using the hydrothermal method. Firstly, $4 \mathrm{~g}$ of starting $\mathrm{TiO}_{2}$ and $40 \mathrm{mg}(1 \mathrm{wt} \%)$ or $200 \mathrm{mg}$ (5 wt\%) of graphene oxide or reduced graphene oxide were mechanically mixed (marked with $M$ ) in the agate mortar. Secondly, $\mathrm{TiO}_{2}$ mixed with $\mathrm{GO}$ or $\mathrm{rGO}$ was placed inside BLH-800 pressure reactor (Berghof Products + Instruments $\mathrm{GmbH}$, Eningen, Germany), $5 \mathrm{~cm}^{3}$ of ultra-pure water or butyl alcohol was added and the reactor was heated up to the programmed temperature $\left(200{ }^{\circ} \mathrm{C}\right)$. The reaction suspension was kept at $200^{\circ} \mathrm{C}$ for $4 \mathrm{~h}$. After that time the pressure valve was opened and the sample was heated for $1 \mathrm{~h}$ without pressure to remove residual alcohol and water. Subsequently, the reactor was cooled down to room temperature. Then, the sample was additionally dried at $105^{\circ} \mathrm{C}$ for $24 \mathrm{~h}$ in a vacuum drier to remove the organic carbon residues and water adsorbed on the surface of photocatalysts. The prepared materials were marked with the letter $A$ in the end of the sample's symbol. For comparison, the $\mathrm{TiO}_{2}-\mathrm{GO}$ and $\mathrm{TiO}_{2}-\mathrm{rGO}$ hybrids were thermally treated without any liquid medium (samples marked as $\mathrm{TiO}_{2}-\mathrm{GO}(1 \mathrm{wt} \% / 5 \mathrm{wt} \%)-\mathrm{A}$ and $\mathrm{TiO}_{2}-\mathrm{rGO}(1 \mathrm{wt} \% / 5 \mathrm{wt} \%)-\mathrm{A}$ ).

\section{Results and Discussion}

Figure 1 presents the XRD patterns of unmodified $\mathrm{TiO}_{2}, \mathrm{TiO}_{2}-\mathrm{GO}$, and $\mathrm{TiO}_{2}-\mathrm{rGO}$ hybrid nanomaterials. The phase composition, crystallite size, and crystallinity parameter (FWHM) of studied materials were listed in Table 1. In general, the peaks corresponding to the anatase phase and weak peak attributed to rutile (110) are observable. The rutile parameters have not been calculated due to the very low content of the rutile phase. Thus, the calculations and conclusions drawn carry a high probability of factual error. The low rutile content does not influence the properties of new composites. 


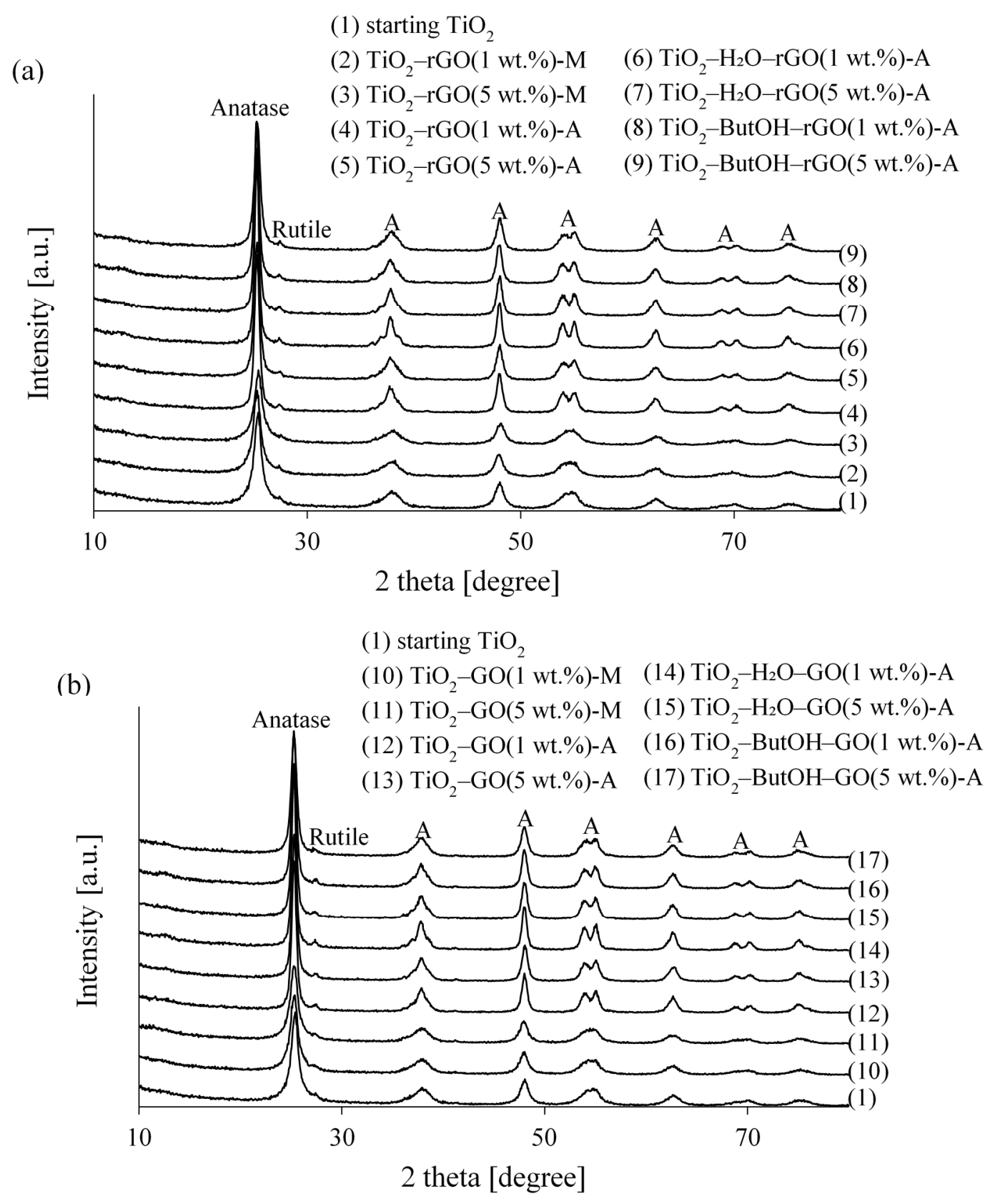

Figure 1. XRD patterns of (a) $\mathrm{TiO}_{2}-\mathrm{rGO}$ and (b) $\mathrm{TiO}_{2}-\mathrm{GO}$ hybrid nanocomposites. 
Table 1. The physicochemical properties of $\mathrm{TiO}_{2}-\mathrm{GO}$ and $\mathrm{TiO}_{2}-\mathrm{rGO}$ nanocomposites.

\begin{tabular}{|c|c|c|c|c|c|c|c|c|}
\hline \multirow{2}{*}{ Sample Code } & \multirow{2}{*}{$\begin{array}{c}\text { Anatase } \\
\text { Content (\%) }\end{array}$} & \multicolumn{2}{|c|}{ Anatase Parameters } & \multirow{2}{*}{$\begin{array}{c}S_{B E T} \\
\left(\mathrm{~m}^{2} / \mathrm{g}\right)\end{array}$} & \multirow{2}{*}{$\begin{array}{c}V_{\text {total }} 0.99 \\
\left(\mathrm{~cm}^{3} / \mathrm{g}\right)\end{array}$} & \multirow{2}{*}{$\begin{array}{c}V_{\text {micro } D R} \\
\left(\mathrm{~cm}^{3} / \mathrm{g}\right)\end{array}$} & \multirow{2}{*}{$\begin{array}{l}V_{m e s o} \\
\left(\mathrm{~cm}^{3} / \mathrm{g}\right)\end{array}$} & \multirow{2}{*}{$\begin{array}{c}\text { Carbon } \\
\text { Content }(w t \%\end{array}$} \\
\hline & & $d_{A} *(\mathrm{~nm})$ & FWHM $\left(^{\circ}\right)$ & & & & & \\
\hline starting $\mathrm{TiO}_{2}$ & 99 & 12 & 0.79 & 312 & 0.27 & 0.11 & 0.16 & 0 \\
\hline $\mathrm{TiO}_{2}-\mathrm{rGO}(1 \mathrm{wt} \%)-\mathrm{M}$ & 99 & 11 & 0.87 & 281 & 0.29 & 0.10 & 0.19 & 1.05 \\
\hline $\mathrm{TiO}_{2}-\mathrm{rGO}(5 \mathrm{wt} \%)-\mathrm{M}$ & 99 & 10 & 0.93 & 268 & 0.27 & 0.10 & 0.17 & 4.54 \\
\hline $\mathrm{TiO}_{2}-\mathrm{rGO}(1 \mathrm{wt} \%)-\mathrm{A}$ & 99 & 18 & 0.56 & 94 & 0.26 & 0.03 & 0.23 & 0.89 \\
\hline $\mathrm{TiO}_{2}-\mathrm{rGO}(5 \mathrm{wt} \%)-\mathrm{A}$ & 99 & 16 & 0.61 & 106 & 0.26 & 0.04 & 0.22 & 4.92 \\
\hline $\mathrm{TiO}_{2}-\mathrm{H}_{2} \mathrm{O}-\mathrm{rGO}(1 \mathrm{wt} \%)-\mathrm{A}$ & 99 & 22 & 0.49 & 83 & 0.35 & 0.03 & 0.32 & 1.07 \\
\hline $\mathrm{TiO}_{2}-\mathrm{H}_{2} \mathrm{O}-\mathrm{rGO}(5 \mathrm{wt} \%)-\mathrm{A}$ & 99 & 20 & 0.52 & 87 & 0.29 & 0.03 & 0.26 & 4.80 \\
\hline $\mathrm{TiO}_{2}-\mathrm{ButOH}-\mathrm{rGO}(1 \mathrm{wt} \%)-\mathrm{A}$ & 99 & 19 & 0.53 & 103 & 0.33 & 0.04 & 0.29 & 1.62 \\
\hline $\mathrm{TiO}_{2}-\mathrm{ButOH}-\mathrm{rGO}(5 \mathrm{wt} \%)-\mathrm{A}$ & 99 & 15 & 0.66 & 111 & 0.27 & 0.04 & 0.23 & 6.27 \\
\hline $\mathrm{TiO}_{2}-\mathrm{GO}(1 \mathrm{wt} \%)-\mathrm{M}$ & 99 & 11 & 0.88 & 253 & 0.29 & 0.09 & 0.20 & 0.50 \\
\hline $\mathrm{TiO}_{2}-\mathrm{GO}(5 \mathrm{wt} \%)-\mathrm{M}$ & 99 & 11 & 0.88 & 266 & 0.37 & 0.12 & 0.25 & 1.80 \\
\hline $\mathrm{TiO}_{2}-\mathrm{GO}(1 \mathrm{wt} \%)-\mathrm{A}$ & 99 & 18 & 0.55 & 93 & 0.32 & 0.03 & 0.29 & 0.44 \\
\hline $\mathrm{TiO}_{2}-\mathrm{GO}(5 \mathrm{wt} \%)-\mathrm{A}$ & 99 & 18 & 0.56 & 98 & 0.31 & 0.04 & 0.31 & 2.50 \\
\hline $\mathrm{TiO}_{2}-\mathrm{H}_{2} \mathrm{O}-\mathrm{GO}(1 \mathrm{wt} \%)-\mathrm{A}$ & 99 & 22 & 0.47 & 86 & 0.35 & 0.03 & 0.32 & 0.56 \\
\hline $\mathrm{TiO}_{2}-\mathrm{H}_{2} \mathrm{O}-\mathrm{GO}(5 \mathrm{wt} \%)-\mathrm{A}$ & 99 & 19 & 0.54 & 100 & 0.33 & 0.04 & 0.29 & 1.99 \\
\hline $\mathrm{TiO}_{2}-\mathrm{ButOH}-\mathrm{GO}(1 \mathrm{wt} \%)-\mathrm{A}$ & 99 & 18 & 0.56 & 99 & 0.38 & 0.04 & 0.34 & 1.76 \\
\hline $\mathrm{TiO}_{2}-\mathrm{ButOH}-\mathrm{GO}(5 \mathrm{wt} \%)-\mathrm{A}$ & 99 & 15 & 0.67 & 122 & 0.32 & 0.04 & 0.28 & 8.38 \\
\hline
\end{tabular}

*-measured at $2 \theta=25.4^{\circ} ; \mathrm{M}-$ mechanical mixing; A—autoclave. 
Figure 1 shows a similar diffraction peak of rGO- and GO-modified composites with starting $\mathrm{TiO}_{2}$. Neither thermal treatment at $200{ }^{\circ} \mathrm{C}$ nor manual mixing cause anatase-to-rutile phase transformation. Moreover, no typical diffraction peak attributed to graphene oxide and its reduced form were found due to the disappearance of the layer-stacking regularity of graphene [15,34]. The absence of a characteristic peak for $\mathrm{rGO}$, independently of the amount of added $\mathrm{rGO}$, located at $24.5^{\circ}$ is due to overlap with the $\mathrm{TiO}_{2}$ anatase peak [35]. In addition, for $\mathrm{TiO}_{2}$ manually mixed with GO and rGO the increase of the FWHM parameters are observable, which may suggest the increase of the crystallinity of the anatase phase. On the other hand, the anatase crystallite size, as well as the shape of the anatase peak do not change. This suggests that the main characteristic peak of rGO is shielded by the anatase peak. It is also noted that the absence of the diffraction peak belonging to $\mathrm{rGO}$ was observed when commercial titanium dioxide was utilized in the preparation process $[35,36]$. This confirms our statement that the hydrothermal method must be considered inefficient for preparation of chemically-bonded composites from commercially available titania and unfunctionalized graphene.

Similar changes are observable for both $\mathrm{TiO}_{2}$ composite materials mechanically mixed with rGO and GO, namely, different amounts of carbon additives do not change the crystallinity and phase composition, which is typical for that kind of processes.

The presence of graphene in obtained nanocomposites was shown on the example of $\mathrm{TiO}_{2}-\mathrm{ButOH}-\mathrm{GO}(5 \mathrm{wt} \%)-\mathrm{A}$ and $\mathrm{TiO}_{2}-\mathrm{ButOH}-\mathrm{rGO}(5 \mathrm{wt} \%)-\mathrm{A}$ samples, as presented in the Figure 2. The SEM images also present the GO and rGO flakes to analyse the morphology of different graphene-based matrices. It can be observed that the GO flake is less than $2 \mu \mathrm{m}$ according to the attached scale and no surface damage was found. The surface is also without any adsorbed impurities. Furthermore, it is possible to observe that the GO flake is folded and consists of a few layers (from three to four layers). The rGO morphology presented in Figure 2c shows the strongly folded structure of the mono- and bi-layer overlapped flakes. The thickness of the rGO matrix is much lower in comparison to the GO sheet. The number of layers of tested GO and rGO was also confirmed by Sobon et al. [37]. Figure $2 \mathrm{~b}$,d shows that the whole surface of GO or rGO sheets are decorated with $\mathrm{TiO}_{2}$ nanoparticles, not mainly the edges of the flakes [17].

(a)

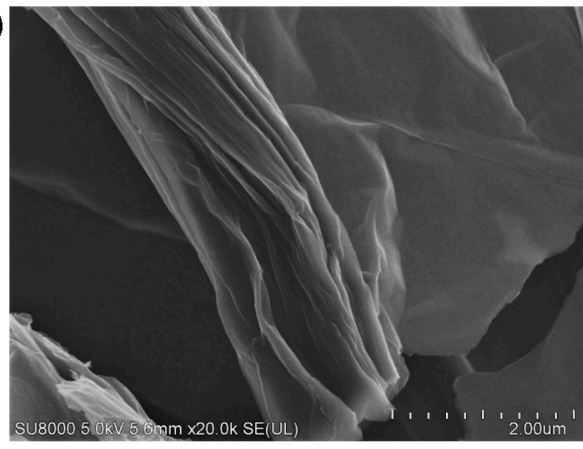

(c)

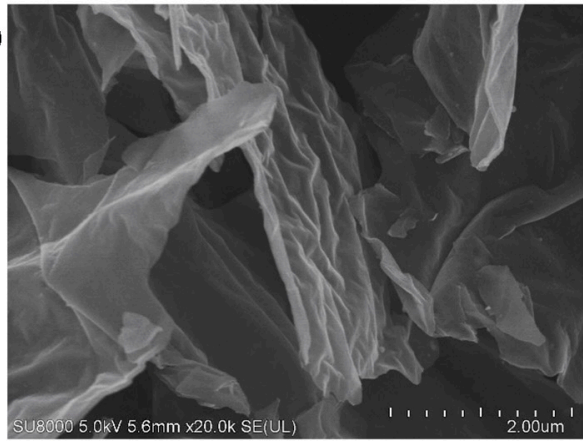

(b)

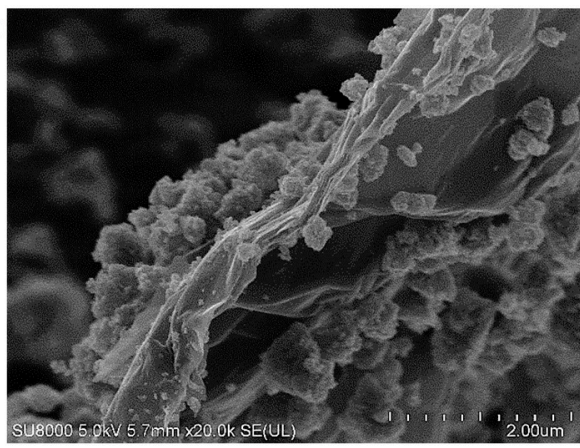

(d)

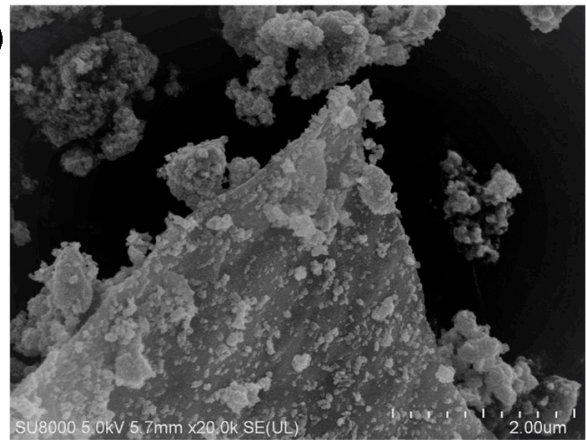

Figure 2. The SEM images of

(a) GO flake;

(b) $\mathrm{TiO}_{2}-\mathrm{GO}(5 \mathrm{wt} \%)-\mathrm{A}$; (c) rGO flakes; and (d) $\mathrm{TiO}_{2}-\mathrm{rGO}(5 \mathrm{wt} \%)-\mathrm{A}$. 
The decrease of specific surface area $\left(S_{B E T}\right)$ of these samples is related to the formation of $\mathrm{TiO}_{2}-\mathrm{rGO}$ and $\mathrm{TiO}_{2}-\mathrm{GO}$ aggregates. The $S_{B E T}$ values measured for $\mathrm{GO}$ and rGO amount to 33 and $62 \mathrm{~m}^{2} / \mathrm{g}$, respectively, which is substantially lower than the theoretical surface area $\left(2630 \mathrm{~m}^{2} / \mathrm{g}\right)$ [38]. According to Li et al. [17] this phenomena is related with the agglomeration of graphene layers during reduction as a result of the van der Waals force between adjacent single layers of graphene. The pore volume distribution for starting $\mathrm{TiO}_{2}$ and modified hybrids changed insignificantly.

Thermal treatment at $200{ }^{\circ} \mathrm{C}$ generally leads to the decrease of the $S_{B E T}$ to ca. $100 \mathrm{~m}^{2} / \mathrm{g}$ due to the increase of the anatase crystallite size. The shape of all peak characteristic for anatase is sharp and narrower (lower FWHM parameters) in comparison with the starting $\mathrm{TiO}_{2}$ and titania nanocomposites manually mixed with rGO or GO. The micropores' volume were reduced due to thermal treatment as well as blocking by rGO and GO sheets, and the mesopores' volume increased twice. These results show rather mesoporous nature of prepared hybrid materials.

The FTIR/DRS spectra of the starting titanium dioxide and $\mathrm{TiO}_{2}-\mathrm{GO}$ or $\mathrm{TiO}_{2}-\mathrm{rGO}$ hybrid nanocomposites are presented in Figure 3. Starting $\mathrm{TiO}_{2}$ is characterized by the presence of a very broad peak in the range $3700-2600 \mathrm{~cm}^{-1}$, which is attributed to hydroxyl groups on different sites $(\mathrm{O}-\mathrm{H}$ stretching of interacting hydroxyl groups, as well as the symmetric and asymmetric O-H stretching modes of molecular water coordinated for $\mathrm{Ti}^{4+}$ ions) [39]. For GO- and rGO-modified nanocomposites the typical broad peak located in the range $3700-3200 \mathrm{~cm}^{-1}$, assigned to the $\mathrm{O}-\mathrm{H}$ stretching vibrations and water molecules adsorbed on the surface of carbon materials [40,41], coincides with the broad peak of $\mathrm{TiO}_{2}$. The characteristic narrow band at $1644 \mathrm{~cm}^{-1}$ is assigned to the molecular water bending mode $\delta_{\mathrm{OH}}$ [9]. TG analysis of utilized titania (presented in our previous work) showed a small mass loss observed at $70-130{ }^{\circ} \mathrm{C}$ related to the release of moisture from the starting $\mathrm{TiO}_{2}$ sample [42]. The broad absorption at $954 \mathrm{~cm}^{-1}$ belongs to the vibration of the $\mathrm{Ti}-\mathrm{O}-\mathrm{Ti}$ and $\mathrm{Ti}-\mathrm{O}$ bonds in $\mathrm{TiO}_{2}$ [43].

The characteristic peaks for reduced graphene oxide at 1240 and $1060 \mathrm{~cm}^{-1}$ assigned to the C-O-C (epoxy) and C-O (alkoxy) stretching vibrations [40,44] respectively, are shown in Figure 3a. These peaks are observed for all modified samples, however the intensity of both is regarded as negligible. This is due to the high effective reduction of GO (studied on the basis of carbon-to-oxygen ratio) [45]. In Figure $4 \mathrm{a}$ the XPS spectra of reference materials: graphene oxide (GO) and reduced graphene oxide (rGO) used to form the composites with $\mathrm{TiO}_{2}$ are shown. Quantitative calculation of the surface composition of GO and rGO indicates that graphene oxide and reduced graphene oxide contain about $52 \mathrm{wt} \%$ and $92 \mathrm{wt} \%$ of carbon, respectively. Elemental analysis confirm the presence of $46 \mathrm{wt} \%$ of carbon in pure GO and $98 \mathrm{wt} \%$ for pure rGO in the bulk. The XPS C 1s line observed for reduced graphene oxide has a different shape from that found for GO. Its maximum is located at $284.2 \mathrm{eV}$ and is characteristic for $\mathrm{sp}^{2} \mathrm{C}-\mathrm{C}$ bonds [46]. The FWHM is relatively low $(1.3 \mathrm{eV})$ indicating that other components of the $\mathrm{C} 1$ s spectrum are not prominent. There is only small asymmetry at about $286 \mathrm{eV}$, which is attributed to minor component coming from $\mathrm{C}-\mathrm{O}$ bonds [47] (possible to observe on FTIR/DRS spectra of rGO-modified materials).

FTIR/DRS analysis of nanocomposites mixed and prepared in the autoclave shows that the intensity of peaks characteristic for $\mathrm{TiO}_{2}$ was lower for samples loaded with $5 \mathrm{wt} \%$ of rGO due to the grey colour of obtained hybrids. In addition, on the basis of FTIR/DRS analysis, some insignificant, but notable, changes in the intensity of hydroxyl groups were observed. Samples heated at $200{ }^{\circ} \mathrm{C}$ in an autoclave are characterized by a lower intensity of $\mathrm{O}-\mathrm{H}$ groups at $3700-2600 \mathrm{~cm}^{-1}$, as well as at $1644 \mathrm{~cm}^{-1}$, which is typical for dehydroxylation of $\mathrm{TiO}_{2}$ surface due to the heat treatment $[36,42,48]$, although the new peaks at 3688 and $3628 \mathrm{~cm}^{-1}$ associated with a stretching vibration modes of isolated hydroxyl groups are observed for heat-treated samples [49]. This stays in accordance with the statement that the higher amount of rGO the lower intensity of absorption peaks. 
(a)

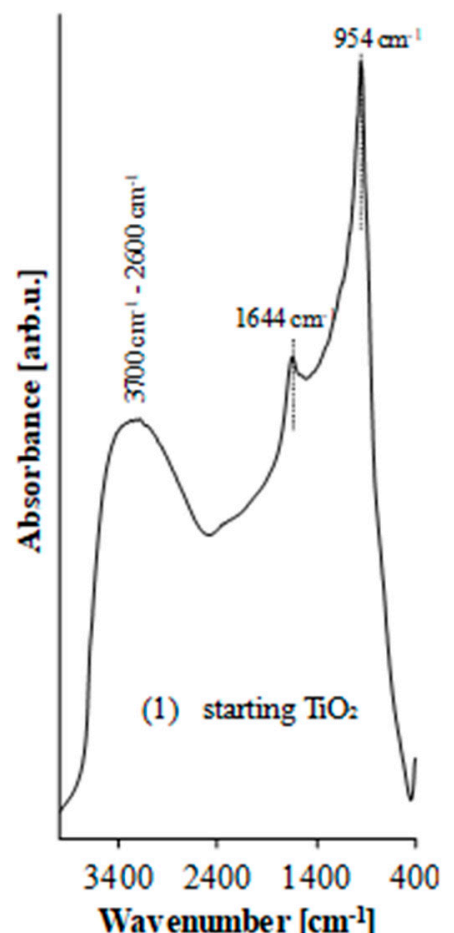

(b)

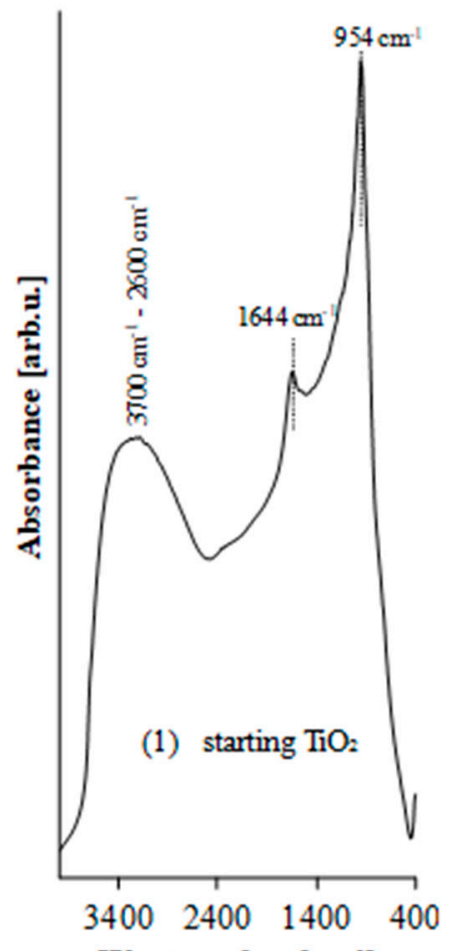

Wavenumber $\left[\mathrm{cm}^{-1}\right]$
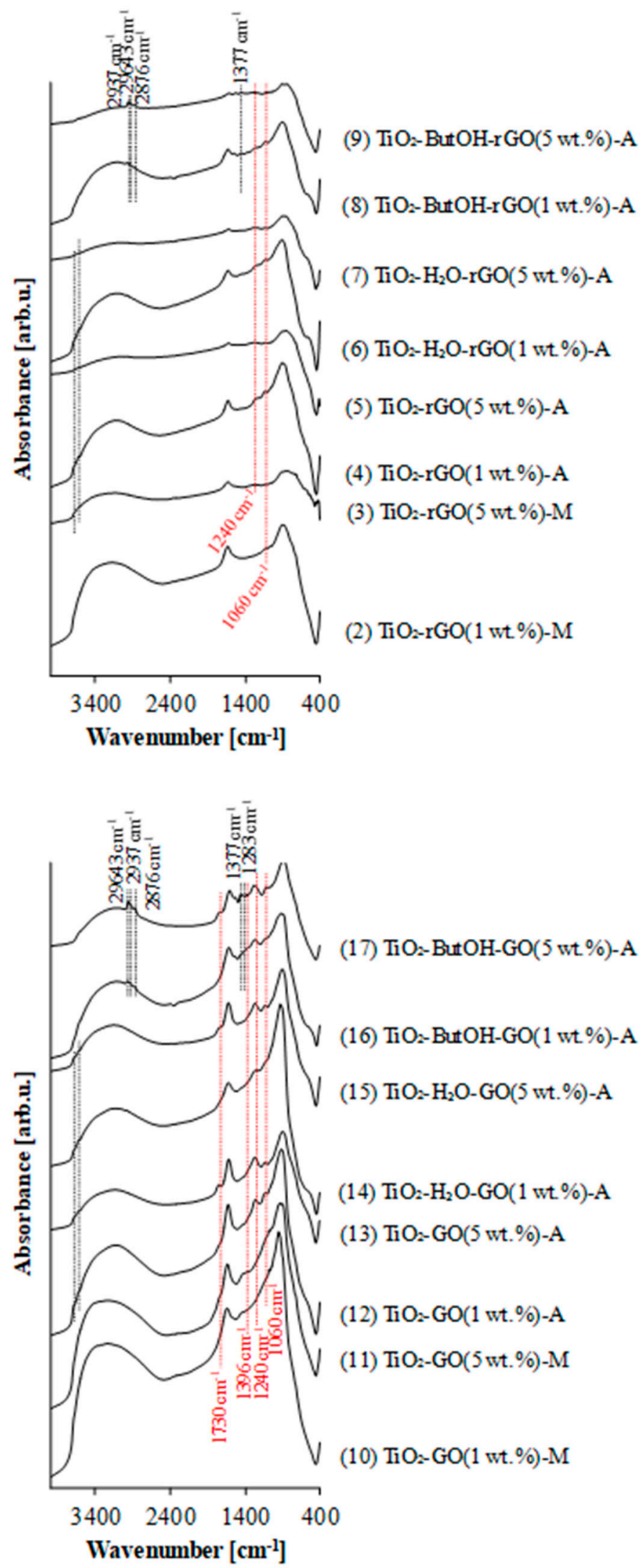

Figure 3. FTIR/DRS spectra of (a) $\mathrm{TiO}_{2}-\mathrm{rGO}$ and (b) $\mathrm{TiO}_{2}-\mathrm{GO}$ hybrid nanocomposite materials. 
The appearance of new peaks at 2963,2937 , and $2876 \mathrm{~cm}^{-1}$ assigned to the $\mathrm{CH}_{3}$ antisymmetric stretching, $\mathrm{CH}_{2}$ symmetric a stretching, $\mathrm{CH}_{3}$ symmetric stretching vibrations, respectively, were found for $\mathrm{rGO}$ and $\mathrm{GO}$ loaded nanocomposites obtained in the presence of 1-butyl alcohol [50-53]. The $\mathrm{C}-\mathrm{O}$ peak characteristic for primary alcohols at $1050 \mathrm{~cm}^{-1}$ is related to $\mathrm{C}-\mathrm{O}$ (alkoxy) stretching vibration at $1060 \mathrm{~cm}^{-1}$ for graphene sheets.

Figure $3 \mathrm{~b}$ presents the FTIR/DRS spectra of GO-modified $\mathrm{TiO}_{2}$ nanocomposites. Apart from the $\mathrm{C}-\mathrm{O}-\mathrm{C}$ (epoxy) and $\mathrm{C}-\mathrm{O}$ (alkoxy) stretching bonds at 1240 and $1060 \mathrm{~cm}^{-1}$ characteristic for rGO, two other peaks may be observed $\left(\mathrm{C}=\mathrm{O}\right.$ stretching of $\mathrm{COOH}$ groups at $1730 \mathrm{~cm}^{-1}$ and $\mathrm{C}-\mathrm{OH}$ at $1396 \mathrm{~cm}^{-1}$ ) [40,44]. According to XPS analysis, the main maximum of $C$ 1s peak of GO is located at $286.7 \mathrm{eV}$ and is attributed to the $\mathrm{C}-\mathrm{O}-\mathrm{C}$ bonds in the graphene oxide framework and additional local maximum at about $285 \mathrm{eV}$ is attributed to the electrons from $\mathrm{C}-\mathrm{C} \mathrm{sp}{ }^{3}$ orbitals [47,54]. A wide shoulder at the low-energy side of the spectrum presumably originates from the presence of $\mathrm{sp}^{2} \mathrm{C}-\mathrm{C}$ bonds. A similar shoulder at the high-energy side of the spectrum (at about $288 \mathrm{eV}$ ) can be attributed to $\mathrm{C}=\mathrm{O}$ bonds. These bonds have also been found in the FTIR/DRS spectra for GO-modified $\mathrm{TiO}_{2}$ samples (more intensive for hybrids with $5 \mathrm{wt} \%$ of GO).

The FTIR/DRS analysis conducted for $\mathrm{TiO}_{2}-\mathrm{GO}$ composites modified in the presence of butyl alcohol shows the appearance of new bonds at 2963, 2937, and $2876 \mathrm{~cm}^{-1}$. These bonds are also found for $\mathrm{TiO}_{2}$-ButOH-rGO samples. Interestingly, the intensity of these peaks increase with the increase of GO content. It can be concluded that the molecules of alcohol has a particular affinity to the GO sheets. This corresponds to the content of carbon listed in Table 1. It was noted that for nanocomposites $\mathrm{TiO}_{2}-\mathrm{GO}(1 \mathrm{wt} \%)-\mathrm{A}$ and $\mathrm{TiO}_{2}-\mathrm{GO}(5 \mathrm{wt} \%)-\mathrm{A}$ the concentration of carbon amounts 0.50 and $2.50 \mathrm{wt} \%$, within for $\mathrm{TiO}_{2}-\mathrm{ButOH}-\mathrm{GO}(1 \mathrm{wt} \%)-\mathrm{A}$ and $\mathrm{TiO}_{2}-\mathrm{ButOH}-\mathrm{GO}(5 \mathrm{wt} \%)-\mathrm{A}$ reaches 1.76 and $8.38 \mathrm{wt} \%$, respectively. According to Wang et al. [55] the chemical bonding of $\mathrm{TiO}_{2}$ nanoparticles with graphene oxide is possible due to the presence of oxygen-containing functional groups mainly located on the edges of GO sheets. In contrary, Georgakilas et al. [56] postulated the presence of functional groups in $\mathrm{GO}$ facilitates the non-covalent functionalization of graphene sheets. The low concentration of edge functional groups may not be beneficial for the covalent bonding of $\mathrm{GO}$ with $\mathrm{TiO}_{2}$ nanoparticles [20].

The surface composition of the $\mathrm{TiO}_{2}$ /graphene composites was analysed with use of X-ray photoelectron spectroscopy (XPS). On the surface of samples GO and rGO only carbon and oxygen were observed. In composites with $\mathrm{TiO}_{2}$ XPS signal originating from titanium atoms was also detected.

The lack of chemical interactions between $\mathrm{TiO}_{2}$ and utilized graphene flakes was also confirmed by means of the FTIR/DRS method. As it was discussed above, starting $\mathrm{TiO}_{2}$ is characterized by the presence of intensive peak at $954 \mathrm{~cm}^{-1}$ assigned to the vibrations of Ti-O and Ti-O-Ti framework bonds [43] (see Figure 4). After graphene modification this peak is broad with decreased intensity. This is due to the dark colour of the obtained samples, as well as the aggregation state of the graphene flakes on its surface. According to Jiang et al. [57] the presence of the Ti-O-C bond at $799 \mathrm{~cm}^{-1}$ proves the chemical interaction between $\mathrm{rGO}$ and $\mathrm{TiO}_{2}$. This peak was not found in our case. Additionally, the UV-VIS/DRS analysis allows to observe no red-shift of the modified $\mathrm{TiO}_{2}$ absorption band edge (see Figure 5). This means that no Ti-O-C and $\mathrm{O}-\mathrm{Ti}-\mathrm{C}$ were formed and the preparation process is only a physical process $[15,18]$. The increase of visible light absorption is strongly related with the grey and dark grey colour of obtained nanocomposites.

In Figure $4 \mathrm{~b}$ the spectrum of the $\mathrm{Ti} 2 \mathrm{p}$ band for the starting $\mathrm{TiO}_{2}$ is compared to an example of $\mathrm{TiO}_{2}$ /graphene composite (namely $\mathrm{TiO}_{2}-\mathrm{GO}(5 \mathrm{wt} \%$ )-A). Both spectra are virtually identical. Since the position of XPS Ti $2 p$ line arbitrarily set the location of the maximum gives no information about the actual chemical state of titanium atoms. It is noteworthy that the full width at half maximum (FWHM) of that line is relatively narrow $(\mathrm{FWHM}=1.3 \mathrm{eV})$ and the line is symmetrical. The shift between $\operatorname{Ti} 2 \mathrm{p}_{3 / 2}$ and Ti $2 \mathrm{p}_{5 / 2}$ is $5.7 \mathrm{eV}$. These observations are in line with the typical spectrum reported for pure $\mathrm{TiO}_{2}$. There are no visible spectral features in the ranges of about $457 \mathrm{eV}$ and $455 \mathrm{eV}$, which are characteristic for $\mathrm{Ti}^{3+}$ ions and $\mathrm{Ti}-\mathrm{C}$ bonds, which are expected if $\mathrm{TiO}_{2}$ interacts with carbon $[58,59]$. 
The XPS Ti $2 p$ line for all other samples discussed in the paper are virtually identical. Consequently, the influence of graphene on the chemical state of titanium atoms is regarded as negligible.

In Figure $4 \mathrm{c}$ the comparison of XPS O 1s lines for starting $\mathrm{TiO}_{2}$ and $\mathrm{TiO}_{2}-\mathrm{GO}(5 \mathrm{wt} \%)-\mathrm{A}$ composite is given. The maximum is located at $530.0 \mathrm{eV}$ and is characteristic for $\mathrm{Ti}-\mathrm{O}$ bonds in $\mathrm{TiO}_{2}$ [31]. The very minor shift between XPS O 1s lines originating from both samples is $0.1 \mathrm{eV}$ and is within an error of the correction procedure used to eliminate charging effects. The peak shape and the maximum shift magnitude observed for other samples considered in the paper are virtually identical. The maximum shift is within $\pm 0.1 \mathrm{eV}$ for all samples. These observations support the conclusion that the $\mathrm{TiO}_{2}$ chemical state is not influenced by the presence of graphene.
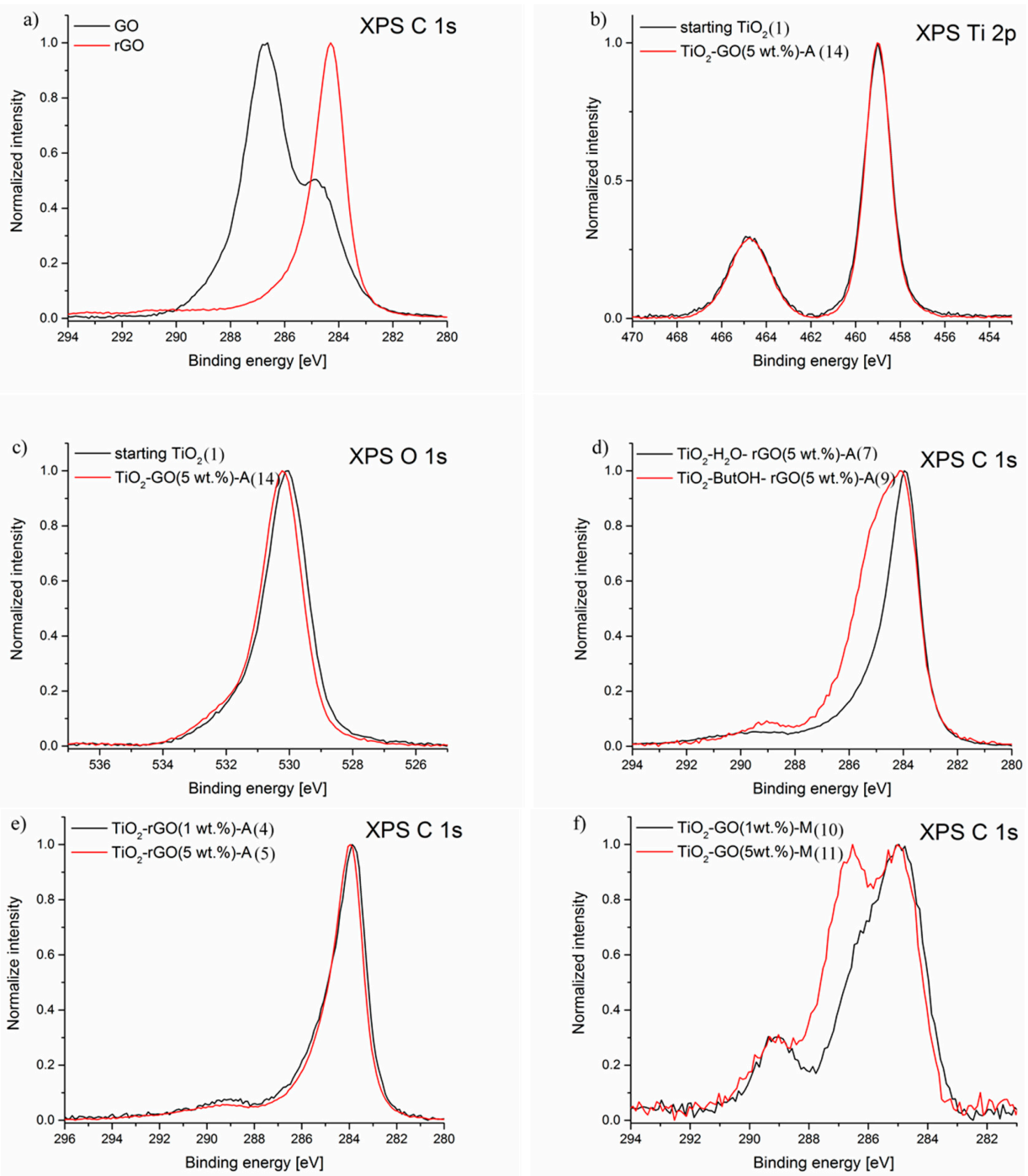

Figure 4. XPS spectra of: (a) Ti $2 \mathrm{p}$ line for starting $\mathrm{TiO}_{2}$ sample and $\mathrm{TiO}_{2}-\mathrm{GO}(5 \mathrm{wt} \%)-\mathrm{A}$ nanocomposite; (b) $\mathrm{O} 1 \mathrm{~s}$ line for starting $\mathrm{TiO}_{2}$ sample and $\mathrm{TiO}_{2}-\mathrm{GO}(5 \mathrm{wt} \%$ )-A nanocomposite; (c) $\mathrm{C} 1 \mathrm{~s}$ line for graphene oxide (GO) and reduced graphene oxide (rGO); (d) $\mathrm{C}$ 1s line for $\mathrm{TiO}_{2}-\mathrm{rGO}$ composites with different solvents used; (e) $\mathrm{C} 1 \mathrm{~s}$ line for samples $\mathrm{TiO}_{2}-\mathrm{rGO}$ treated in autoclave with different concentrations of rGO; and the (f) $\mathrm{C}$ 1s line for samples $\mathrm{TiO}_{2}$-GO mixed manually with different concentrations of GO.

Since no significant changes of chemical states of titanium and oxygen were observed, the surface state of the graphene is the only tool to find an insight into $\mathrm{TiO}_{2}$-graphene interactions. Different types of influence on the chemical state of the graphene oxide and reduced graphene oxide are expected after their mixing with $\mathrm{TiO}_{2}$. In Figure $4 \mathrm{~d}$ the comparison between the chemical state of the surface of 
two samples of rGO mixed with $\mathrm{TiO}_{2}$ in autoclave are shown. They were mixed in different solvents: water (marked as $\mathrm{TiO}_{2}-\mathrm{H}_{2} \mathrm{O}-\mathrm{rGO}\left(5 \mathrm{wt} \%\right.$ )-A) and butanol (marked as $\mathrm{TiO}_{2}-\mathrm{ButOH}-\mathrm{rGO}(5 \mathrm{wt} \%)-\mathrm{A}$ ). The spectrum obtained for the sample mixed with water is virtually identical to the spectrum of pure rGO (see Figure 4a). However, the XPS C 1s spectrum coming from the sample mixed in butanol is much wider $(F W H M=2.4 \mathrm{eV})$ than the spectrum obtained for the former sample $(\mathrm{FWHM}=1.4 \mathrm{eV})$. There is very prominent shoulder at the high-energy side of the $\mathrm{C} 1$ s line in the region of about $286 \mathrm{eV}$. This position is characteristic for the $C 1$ s spectrum of alcohols. Therefore, the resulting spectrum is considered as a superposition of the signal originating from rGO covered partly with butanol. On the basis of FTIR/DRS analysis it was also noticed that the intensity of peaks at 2963, 2937, and $2876 \mathrm{~cm}^{-1}$ assigned to the alkyl groups increase with the increase of rGO (as well as GO) content (see Figure 3). The amount of butyl alcohol was constant for all preparation processes $\left(5 \mathrm{~cm}^{3}\right)$. This could be related to the covering of graphene flakes with butanol, as determined by the XPS measurements.

In Figure 4e the XPS spectra from $\mathrm{TiO}_{2}-\mathrm{rGO}$ composites with different loads of rGO are shown. In the case of reduced graphene oxide there is no observable influence of the amount of the rGO added to the mixture ( $1 \mathrm{wt} \%$ or $5 \mathrm{wt} \%$ ). Both $\mathrm{C} 1 \mathrm{~s}$ lines are virtually identical with the reference spectrum of rGO. There was also no difference in the surface composition of the $\mathrm{TiO}_{2}-\mathrm{rGO}$ composites considering different mixing type, manual or in the autoclave. However, the FTIR/DRS analysis confirm the increase of the intensity of peaks characteristic for $\mathrm{C}-\mathrm{O}$ and $\mathrm{C}-\mathrm{O}-\mathrm{C}$ bonds for samples loaded with $5 \mathrm{wt} \%$ of $\mathrm{rGO}$.

Considering mixing of $\mathrm{TiO}_{2}$ with graphene oxide much more prominent changes are observed. In Figure $4 \mathrm{e}$ the chemical state of carbon is compared for two samples mixed manually with different amounts of GO. The spectrum of the $\mathrm{TiO}_{2}-\mathrm{GO}(1 \mathrm{wt} \%)-\mathrm{M}$ sample has a maximum at about $285 \mathrm{eV}$ and its envelope is very similar to the adventitious carbon observed on the pure $\mathrm{TiO}_{2}$. The envelope of the XPS C 1s line coming from $\mathrm{TiO}_{2}-\mathrm{GO}(5 \mathrm{wt} \%)-\mathrm{M}$ sample is much different. There are two main maxima. The first is located at about $285 \mathrm{eV}$ and the second at $286.7 \mathrm{eV}$. The second maximum is identical with the maximum observed for the reference spectrum of GO (see Figure $4 \mathrm{a}$ ). Therefore, the former spectrum is considered as a superposition of XPS C 1s signal coming from the surface of $\mathrm{TiO}_{2}$ covered with adventitious carbon and XPS C 1s signal originating from GO. This can indicate that the manual mixing of $\mathrm{GO}$ with $\mathrm{TiO}_{2}$ is inefficient. Mixing of $\mathrm{GO}$ with $\mathrm{TiO}_{2}$ in the autoclave results in the almost identical spectrum for both small and high concentration of GO and are both similar to the spectrum of $\mathrm{TiO}_{2}-\mathrm{GO}(1 \mathrm{wt} \%)-\mathrm{M}$ sample.

It is also worth mentioning that thermal treatment in a high-pressure atmosphere does not cause the reduction of GO to rGO. It has been reported in previously-published papers that the decomposition of oxygen-containing functional groups in GO occurs at ca. $200{ }^{\circ} \mathrm{C}[19,57,60]$. In this case, the FTIR/DRS as well as XPS analysis for $\mathrm{TiO}_{2}-\mathrm{GO}(1 \mathrm{wt} \%)-\mathrm{M}$ and $\mathrm{TiO}_{2}-\mathrm{GO}(1 \mathrm{wt} \%)-\mathrm{A}$ confirm the presence of several groups characteristic for graphene oxide. On the basis of quantitative calculation of the surface composition and quantitative elemental analysis of the above-mentioned samples, no significant changes in carbon content before and after thermal treatment was found. It could be concluded that the hydrothermal reduction of GO did not occur. However, XPS study for $\mathrm{TiO}_{2}-\mathrm{GO}(5 \mathrm{wt} \%)$-A confirms almost total reduction of GO in the tested sample (C 1s signal very similar to $\left.\mathrm{TiO}_{2}-\mathrm{rGO}(5 \mathrm{wt} \%)-\mathrm{A}\right)$. Hence, the amount of $1 \mathrm{wt} \%$ of carbon is to less to observe changes typical for thermal reduction of GO to $\mathrm{rGO}$. Interestingly, the FTIR/DRS analysis for $\mathrm{TiO}_{2}-\mathrm{GO}(5 \mathrm{wt} \%)-\mathrm{A}$ proves the presence of typical peaks characteristic for GO. These results suggest the surface reduction of GO, thus, no bulk-reduction occurs.

The light absorption abilities of tested hybrids were obtained by UV-VIS-diffuse reflection spectroscopy (UV-VIS/DRS absorption spectra presented in Figure 5). The starting $\mathrm{TiO}_{2}$ displays a typical absorption with an intense transition in UV region (assigned to the intrinsic band gap absorption of titania) [22]. For both kinds of modification (with GO and rGO) slight change of band gap energy was noticed. This means that no carbon doping occurred, as mentioned previously. Qianqian et al. [15] concluded that an insignificant bathochromic shift occurs because of the impurity level. The GO or 
rGO sheets were decorated with $\mathrm{TiO}_{2}$ nanoparticles [36]. In addition, the absorption peak at $230 \mathrm{~nm}$ attributed to the $\pi-\pi^{*}$ plasmon peak (corresponding to the aromatic $\mathrm{C}=\mathrm{C}$ single bond) was found for GO- [61,62] and rGO-modified materials. For GO-loaded composites no absorption peak at 290-310 nm corresponding to a $\mathrm{n}-\pi^{*}$ plasmon peak was possible to observe due to the high UV absorption of $\mathrm{TiO}_{2}$. According to Saxena et al. [63] this $\mathrm{n}-\pi^{*}$ plasmon peak is characteristic for epoxide $\mathrm{C}-\mathrm{O}-\mathrm{C}$ and peroxide $\mathrm{R}-\mathrm{O}-\mathrm{O}-\mathrm{R}$ like linkages. Kumar et al. [64] have assigned the $\mathrm{n}-\pi^{*}$ transition to the $\mathrm{C}=\mathrm{O}$ bonds, which could disappear or decrease in intensity upon reduction due to the elimination of $\mathrm{C}=\mathrm{O}$ bonds. The $\mathrm{C}-\mathrm{O}-\mathrm{C}$, as well as $\mathrm{C}=\mathrm{O}$ bonds, were analysed by means of both FTIR/DRS and XPS spectroscopy. Interestingly, no red-shift of $230 \mathrm{~nm}$ bond is observed for rGO-loaded hybrids. This red-shift to 260-290 $\mathrm{nm}$ is characteristic for reduction of graphene oxide due to an increase in the restored carbon network conjugation length $[62,65,66]$. However, some reduction procedures, e.g., thermal treatment in water, do not result in a red-shift of $\pi-\pi^{*}$ plasmon peak [67].
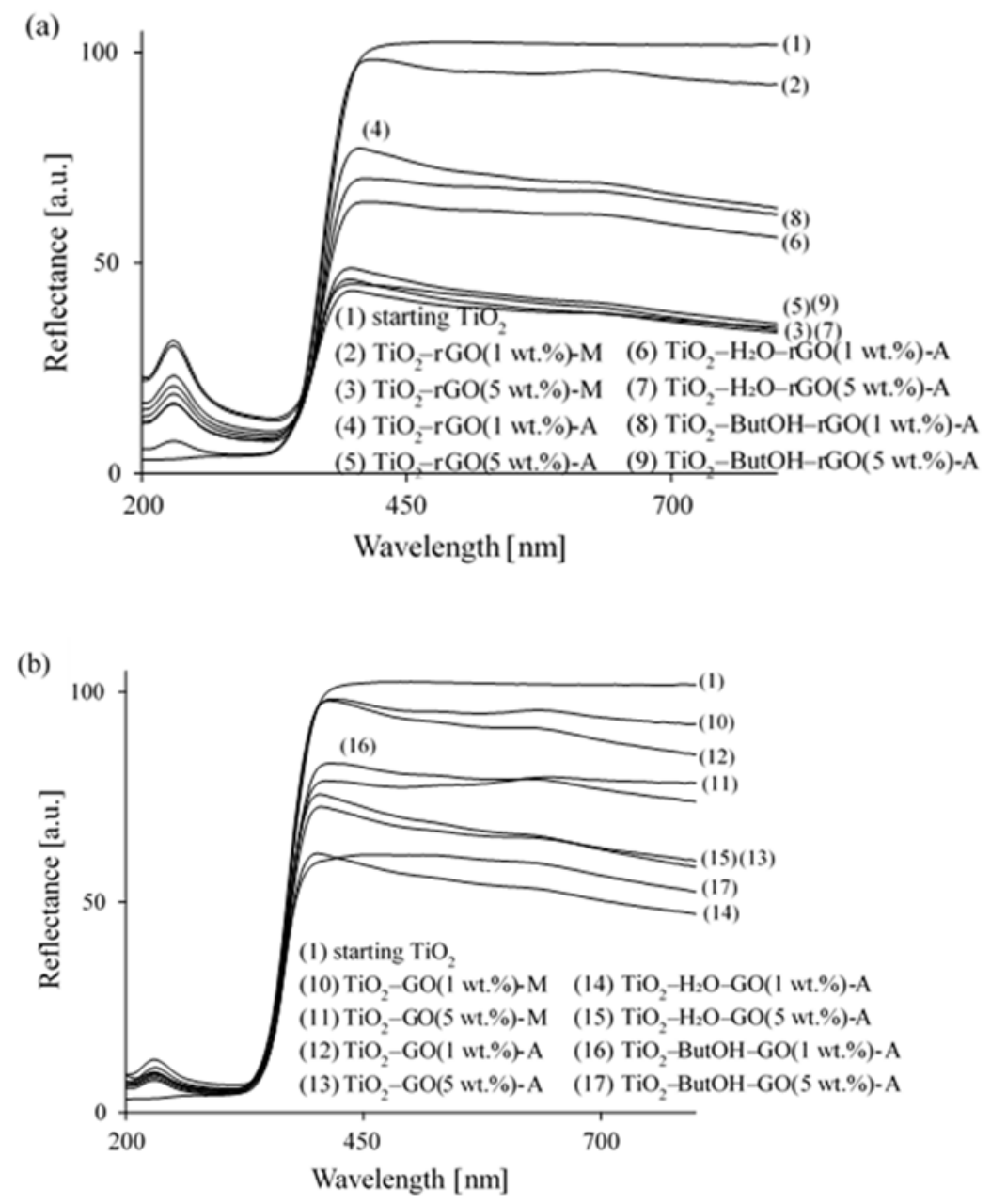

Figure 5. UV-VIS/DRS spectra of (a) $\mathrm{TiO}_{2}-\mathrm{rGO}$ and (b) $\mathrm{TiO}_{2}-\mathrm{GO}$ hybrid nanocomposites.

Enhanced visible light absorption occurs due to the colour changes of hybrids modified with GO or rGO changed the colour from white to grey and dark grey, respectively $[65,68]$. The starting $\mathrm{TiO}_{2}$ strongly reflects visible light due to the white colour. Gurunathan et al. [69] concluded that the black colour of the reduced graphene oxide indicates the deoxygenation resulting in electronic conjugation within the reduced sheets. In this case, UV-VIS/DRS analysis does not offer a clear answer to the question of whether the GO was reduced successfully (confirmed by means of elemental analysis, FTIR/DRS and XPS). 


\section{Conclusions}

Summarizing, this paper presents the characterization of structural and textural properties of $\mathrm{TiO}_{2}$ hybrid nanocomposites modified with different graphene-related materials (reduced graphene oxide and graphene oxide) prepared by the hydrothermal method in a high-pressure atmosphere. Synopsizing information presented in this article, the following general conclusions can be drawn:

- Preparation method: the hydrothermal method must be considered to be inefficient for preparation of chemically-bonded composites synthesized from commercially available $\mathrm{TiO}_{2}$ and unfunctionalized graphene-related sheets (prepared from graphite). Hydrothermal treatment at $200{ }^{\circ} \mathrm{C}$ caused a reduction of $\mathrm{GO}$ to $\mathrm{rGO}$ in $\mathrm{TiO}_{2}-\mathrm{GO}$ nanocomposites, however, this phenomena was observed for samples containing $5 \mathrm{wt} \%$ of $\mathrm{GO}$.

- Interactions: lack of chemical bands between $\mathrm{TiO}_{2}$ and utilized graphene materials is due to the application of commercial titania from sulphate technology. $\mathrm{TiO}_{2}$ nanoparticles were loaded on GO or rGO flakes;

- Chemical bonding analysis: utilization of at least XPS, FTIR/DRS, and UV-VIS/DRS methods is sufficient to prove the presence of chemical interactions between $\mathrm{TiO}_{2}$ and graphene-based materials. All analysis must be conducted with enhanced caution due to the strong influence of standard measurements on the chemical and electronic structures of graphene.

Author Contributions: Conceptualization: E.K.-N.; investigation: E.K.-N., D.M., J.K.-K. and A.W.; methodology: E.K.-N.; supervision: A.W.M.; writing—original draft: E.K.-N., D.M. and J.K.-K.; writing—review and editing: E.K.-N. and A.W.M.

Acknowledgments: This work was supported by grant DEC-2012/06/A/ST5/00226 from the National Science Centre, Poland.

Conflicts of Interest: The authors declare no conflict of interest.

\section{References}

1. Ji, T.; Sun, M.; Han, P. A review of the preparation and applications of graphene/semiconductor composites. Carbon 2014, 70, 319-322. [CrossRef]

2. Okoth, O.K.; Yan, K.; Zhang, J. Mo-doped $\mathrm{BiVO}_{4}$ and graphene nanocomposites with enhanced photoelectrochemical performance for aptasensing of streptomycin. Carbon 2017, 120, 194-202. [CrossRef]

3. Kong, L.B.; Boy, F.; Huang, Y.; Xu, Z.J.; Zhou, K.; Li, S.; Que, W.; Huang, H.; Zhang, T. Graphene-Inorganic Hybrids (I). In Carbon Nanomaterials Based on Graphene Nanosheets, 1st ed.; Kong, L.B., Ed.; CRS Press: Boca Raton, FL, USA, 2017; pp. 111-220, ISBN 9781498725057.

4. Lin, F.; Xiang, J.; Wang, J.; Yang, S.; Li, H.; Meng, X.; Liu, X.; Wang, M. Solvothermal synthesis of graphene-CdS nanocomposites for high efficient visible-light photocatalyst. J. Alloys Compd. 2013, 551, 327-333.

5. Hu, C.; Lu, T.; Chen, F.; Zhang, R. A brief review of graphene-metal oxide composites synthesis and application in photocatalysis. J. Chin. Adv. Mater. Soc. 2013, 1, 21-39. [CrossRef]

6. Huang, Y.; Chen, D.; Hu, X.; Qian, Y.; Li, D. Preparation of $\mathrm{TiO}_{2} /$ carbon nanotubes/reduced graphene oxide composites with enhanced photocatalytic activity for the degradation of rhodamine B. Nanomaterials 2018, 8, 431. [CrossRef] [PubMed]

7. Akhavan, O.; Ghaderi, E. Photocatalytic reduction of graphene-oxide nanosheets on $\mathrm{TiO}_{2}$ thin film for photoinactivation of bacteria in solar light irradiation. J. Phys. Chem. C 2009, 113, 20214-20220. [CrossRef]

8. Chen, C.; Cai, W.; Long, M.; Zhou, B.; Wu, Y.; Wu, D.; Feng, Y. Synthesis of visible-light responsive graphene oxide $/ \mathrm{TiO}_{2}$ composites with $\mathrm{p} / \mathrm{n}$ heterojunction. ACS Nano 2010, 11, 6425-6432. [CrossRef] [PubMed]

9. Zhang, Y.; Tang, Z.-R.; Fu, X.; Xu, Y.-J. TiO 2 -graphene nanocomposites for gas-phase photocatalytic degradation of volatile aromatic pollutant: Is $\mathrm{TiO}_{2}$-graphene truly different from other $\mathrm{TiO}_{2}$-carbon composite materials? ACS Nano 2010, 12, 7303-7314. [CrossRef] [PubMed]

10. Stengl, V.; Popelková, D.; Vlacil, P. $\mathrm{TiO}_{2}$-graphene nanocomposites as high performance photocatalysts. J. Phys. Chem. C 2011, 115, 25209-25218. [CrossRef] 
11. Perera, S.D.; Mariano, R.G.; Vu, K.; Nour, N.; Seitz, O.; Chabal, Y.; Balkus, K.J., Jr. Hydrothermal synthesis of graphene- $\mathrm{TiO}_{2}$ nanotube composites with enhanced photocatalytic activity. ACS Catal. 2012, 2, 949-956. [CrossRef]

12. Tang, B.; Chen, H.; Peng, H.; Wang, Z.; Huang, W. Graphene Modified $\mathrm{TiO}_{2}$ Composite Photocatalysts: Mechanism, Progress and Perspective. Nanomaterials 2018, 8, 105. [CrossRef] [PubMed]

13. Ali, I.; Kim, J.-O. Continuous-Flow Photocatalytic degradation of organics using modified $\mathrm{TiO}_{2}$ nanocomposites. Catalysts 2018, 8, 43. [CrossRef]

14. Zhang, H.; Lv, X.; Li, Y.; Wang, Y.; Li, J. P25-graphene composite as a high performance photocatalyst. ACS Nano 2010, 4, 380-386. [CrossRef] [PubMed]

15. Qianqian, Z.; Tang, B.; Guoxin, H. High photoactive and visible-light responsive graphene/titanate nanotubes photocatalysts: Preparation and characterization. J. Hazard. Mater. 2011, 198, 78-86. [CrossRef] [PubMed]

16. Shu, W.; Liu, Y.; Peng, Z.; Chen, K.; Zang, C.; Chen, W. Synthesis and photovoltaic performance of reduced graphene oxide- $\mathrm{TiO}_{2}$ nanoparticles composites by solvothermal method. J. Alloys Compd. 2013, 563, 229-233. [CrossRef]

17. Li, J.; Zhou, S.I.; Hong, G.-B.; Chang, C.-T. Hydrothermal preparation of P25-graphene composite with enhanced adsorption and photocatalytic degradation of dyes. Chem. Eng. J. 2013, 219, 486-491. [CrossRef]

18. Qiu, B.; Zhou, Y.; Ma, Y.; Yang, X.; Sheng, W.; Xing, M.; Zhang, J. Facile synthesis of the Ti ${ }^{3+}$ self-doped $\mathrm{TiO}_{2}$-graphene nanosheet composites with enhanced photocatalysis. Sci. Rep. 2015, 5, 8591. [CrossRef] [PubMed]

19. Liang, D.; Cui, C.; Hu, H.; Wang, Y.; Xu, S.; Ying, B.; Li, P.; Lu, B.; Shen, H. One-step hydrothermal synthesis of anatase $\mathrm{TiO}_{2}$ /reduced graphene oxide nanocomposites with enhanced photocatalytic activity. J. Alloys Compd. 2014, 582, 236-240. [CrossRef]

20. Wang, W.-S.; Wang, D.-H.; Qu, W.-G.; Lu, L.-Q.; Xu, A.-W. Large ultrathin anatase $\mathrm{TiO}_{2}$ nanoshhets with exposed $\{001\}$ facets on graphene for enhanced visible light photocatalytic activity. J. Phys. Chem. C 2012, 116, 19893-19901. [CrossRef]

21. Shi, M.; Shen, J.; Ma, H.; Li, Z.; Lu, X.; Li, N.; Ye, M. Preparation of graphene-TiO 2 composite by hydrothermal method from peroxotitanium acid and its photocatalytic properties. Colloids Surf. A 2012, 405, 30-37. [CrossRef]

22. Tan, L.-L.; Ong, W.-J.; Chai, S.-P.; Mohamed, A.R. Reduced graphene oxide-TiO 2 nanocomposite as a promising visible-light- active photocatalyst for the conversion of carbon dioxide. Nanoscale Res. Lett. 2013, 8, 465-469. [CrossRef] [PubMed]

23. Zhang, D.; Pu, X.; Ding, G.; Shao, X.; Gao, Y.; Liu, J.; Gao, M.; Li, Y. Two-phase hydrothermal synthesis of $\mathrm{TiO}_{2}$-graphene hybrids with improved photocatalytic activity. J. Alloys Compd. 2013, 572, 1999-2004. [CrossRef]

24. Dong, L.; Li, M.; Dong, L.; Zhao, M.; Feng, J.; Han, Y.; Deng, J.; Li, X.; Li, D.; Sun, X. Hydrothermal synthesis of mixed crystal phases $\mathrm{TiO}_{2}$-reduced graphene oxide nanocomposites with small particle size for lithium ion batteries. Int. J. Hydrog. Energy 2014, 39, 16116-16122. [CrossRef]

25. Liu, Y. Hydrothermal synthesis of $\mathrm{TiO}_{2}-\mathrm{rGO}$ composites and their improved photocatalytic activity in visible light. RSC Adv. 2014, 4, 36040-36045. [CrossRef]

26. Bai, X.; Zhand, X.; Hua, Z.; Ma, W.; Dai, Z.; Huang, X.; Gu, H. Uniformly distributed anatase $\mathrm{TiO}_{2}$ nanoparticles on graphene: Synthesis, characterization, and photocatalytic application. J. Alloys Compd. 2014, 599, 10-18. [CrossRef]

27. Kusiak-Nejman, E.; Wanag, A.; Kapica-Kozar, J.; Morawski, A.W. Preparation and characterization of $\mathrm{TiO}_{2}$ thermally modified with cyclohexane vapours. Int. J. Mater. Prod. Technol. 2016, 52, 286-297. [CrossRef]

28. Morawski, A.W.; Kusiak-Nejman, E.; Wanag, A.; Kapica-Kozar, J.; Wróbel, R.; Ohtani, B.; Aksienionek, M.; Lipińska, L. Photocatalytic degradation of acetic acid in the presence of visible light-active $\mathrm{TiO}_{2}$-reduced graphene oxide photocatalysts. Catal. Today 2017, 280, 108-113. [CrossRef]

29. Tanuma, S.-I.; Palnichenko, A.V.; Satch, N. Synthesis of low density carbon crystals by quenching gasous carbon and intercalation of alkali atoms into these crystals. Synth. Met. 1995, 71, 1841-1844. [CrossRef]

30. Dolat, D.; Mozia, S.; Wróbel, R.J.; Moszyński, D.; Ohtani, B.; Guskos, N.; Morawski, A.W. Nitrogen-doped, metal-modified rutile titanium dioxide as photocatalysts for water remediation. Appl. Catal. B 2015, 162, 310-318. [CrossRef] 
31. Regonini, D.; Jaroenworaluck, A.; Stevens, R.; Bowen, C.R. Effect of heat treatment on the properties and structure of $\mathrm{TiO}_{2}$ nanotubes: Phase composition and chemical composition. Surf. Interface Anal. 2010, 42, 139-144. [CrossRef]

32. Yu, C.; Yu, J.C. A Simple Way to Prepare C-N-codoped $\mathrm{TiO}_{2}$ photocatalyst with visible-light activity. Catal. Lett. 2009, 129, 462-470. [CrossRef]

33. Rogala, M.; Dabrowski, P.; Kowalczyk, P.J.; Wlasny, I.; Kozlowski, W.; Busiakiewicz, A.; Karaduman, I.; Lipińska, L.; Baranowski, J.M.; Klusek, Z. The observer effect in graphene oxide- How the standard measurements affect the chemical and electronic structure. Carbon 2016, 103, 235-241. [CrossRef]

34. Bourlinos, A.B.; Gournis, D.; Petridis, D.; Szabo, T.; Szeri, A.; Dekany, I. Graphite oxide: chemical reduction to graphite and surface modification with primary aliphatic amines and amino acids. Langmuir 2003, 19, 6050-6055. [CrossRef]

35. Stengl, V.; Henych, J.; Vomacka, P.; Slusna, M. Doping of $\mathrm{TiO}_{2}-\mathrm{GO}$ and $\mathrm{TiO}_{2}-\mathrm{rGO}$ with noble metals: Synthesis, characterization and photocatalytic performance for azo dyes decomposition. Photochem. Photobiol. 2013, 89, 1038-1046. [CrossRef] [PubMed]

36. Kusiak-Nejman, E.; Wanag, A.; Kowalczyk, Ł.; Kapica-Kozar, J.; Colbeau-Justin, C.; Mendez Medrano, M.G.; Morawski, A.W. Graphene-oxide $\mathrm{TiO}_{2}$ and reduced graphene oxide- $\mathrm{TiO}_{2}$ nanocomposites: Insight in charge-carrier lifetime measurements. Catal. Today 2017, 287, 189-195. [CrossRef]

37. Sobon, G.; Sotor, J.; Jagiello, J.; Kozinski, R.; Zdrojek, M.; Holdynski, M.; Paletko, P.; Boguslawski, J.; Lipinska, L.; Abramski, K.M. Graphene oxide vs. reduced graphene oxide as saturable absorbers for er-dopped positively mode-locked fiber laser. Opt. Express 2012, 17, 19463-19473. [CrossRef] [PubMed]

38. Lee, C.; Wei, X.; Kysar, J.W.; Hone, J. Measurement of the elastic properties and intrinsic strength of monolayer graphene. Science 2008, 321, 385-388. [CrossRef] [PubMed]

39. Winter, M.; Hamal, D.; Yang, X.; Kwen, H.; Jones, D.; Rajagopalan, S.; Klabunde, K.J. Defining reactivity of solid sorbents: what is the most appropriate metric? Chem. Mater. 2009, 21, 2367-2374. [CrossRef]

40. Abdelhosseninzadeh, S.; Asgharzadek, H.; Kim, H.S. Fast and fully-scalable synthesis of reduced graphene oxide. Sci. Rep. 2015, 5, 10160. [CrossRef] [PubMed]

41. Randorn, S.; Wongnawa, P.; Boonsin, P. Bleaching of Methylene Blue by Hydrated Titanium Dioxide. Sci. Asia 2004, 30, 149-156. [CrossRef]

42. Morawski, A.W.; Kusiak-Nejman, E.; Przepiórski, J.; Kordala, R.; Pernak, J. Cellulose-TiO ${ }_{2}$ nanocomposite with enhanced UV-Vis light absorption. Cellulose 2013, 20, 1293-1300. [CrossRef]

43. Bezrodna, T.; Gavrilko, T.; Puchkovska, G.; Shimanovska, V.; Baran, J.; Marchewka, M. Spectroscopic study of $\mathrm{TiO}_{2}$ (rutile)-benzophenone heterogeneous systems. J. Mol. Struct. 2002, 614, 315-324. [CrossRef]

44. Yao, Y.; Chen, X.; Zhu, J.; Zeng, B.; Wu, Z.; Li, X. The effect of ambient humidity on the electrical properties of the graphene oxide films. Nanoscale Res. Lett. 2012, 7, 363-370. [CrossRef] [PubMed]

45. Zhang, W.; Guo, H.; Sun, H.; Zheng, R.C. Hydrothermal synthesis and photoelectrochemical performance enhancement of $\mathrm{TiO}_{2}$ /graphene composite in photo-generated cathodic protection. Appl. Surf. Sci. 2016, 382, 128-134. [CrossRef]

46. Yamada, Y.; Kim, J.; Matsuo, S.; Sato, S. Nitrogen-containing graphene analyzed by X-ray photoelectron spectroscopy. Carbon 2014, 70, 59-74. [CrossRef]

47. Wilamowska, M.; Kujawa, M.; Michalska, M.; Lipińska, L.; Lisowska-Oleksiak, A. Electroactive polymer/graphene oxide nanostructured composites; evidence for direct chemical interactions between PEDOT and GOx. Synth. Met. 2016, 220, 334-346. [CrossRef]

48. Kusiak-Nejman, E.; Wanag, A.; Kapica-Kozar, J.; Kowalczyk, L.; Morawski, A.W. Modification of titanium dioxide with graphitic carbon from anthracene thermal decomposition as a promising method for visible-active photocatalysts preparation. J. Adv. Oxid. Technol. 2016, 19, 227-235. [CrossRef]

49. Zhu, J.; Yang, J.; Bian, Z.-F.; Ren, J.; Liu, Y.-M.; Cao, Y.; Li, H.-X.; He, H.-Y.; Fan, K.-N. Nanocrystalline anatase $\mathrm{TiO}_{2}$ photocatalysts prepared via a facile low temperature nanhydrolytic sol-gel reaction of $\mathrm{TiCl}_{4}$ and benzyl alcohol. Appl. Catal. B Environ. 2007, 76, 82-91. [CrossRef]

50. Kipkemboi, P.K.; Kiprono, P.C.; Sanga, J.J. Vibrational spectra of $t$-butyl alcohol, $t$-butylamine and $t$-butyl alcohol $+t$-butylamine binary liquid mixtures. Bull. Chem. Soc. Ethiop. 2003, 17, 211-218.

51. NIST Chemistry WebBook. Available online: https://webbook.nist.gov/cgi/cbook.cgi?ID=71-36-3\&Type= IR-SPEC\&Index=QUANT-IR,9 (accessed on 31 July 2009). 
52. Dolat, D.; Quici, N.; Kusiak-Nejman, E.; Morawski, A.W.; Li Puma, G. One-step, hydrothermal synthesis of nitrogen, carbon co-doped titanium dioxide $\left(\mathrm{N}, \mathrm{C}-\mathrm{TiO}_{2}\right)$ photocatalysts. Effect of alcohol degree and chain length as carbon dopant precursors on photocatalytic activity and catalyst deactivation. Appl. Catal. B Environ. 2012, 115-116, 81-89. [CrossRef]

53. Kusiak-Nejman, E.; Janus, M.; Grzmil, B.; Morawski, A.W. Methylene Blue decomposition under visible light irradiation in the presence of carbon-modified $\mathrm{TiO}_{2}$ photocatalysts. J. Photochem. Photobiol. A Chem. 2011, 226, 68-72. [CrossRef]

54. Zhou, S.; Kim, S.; Bongiorno, A. Chemical structure of oxidized multilayer epitaxial graphene: A density functional theory study. J. Phys. Chem. C 2013, 117, 6267-6274. [CrossRef]

55. Wang, P.; Zhai, Y.M.; Wang, D.J.; Dong, S.J. Synthesis of reduced graphene oxide-anatase $\mathrm{TiO}_{2}$ nanocomposite and its improved photo-induced charge transfer properties. Nanoscale 2011, 3, 1640-1645. [CrossRef] [PubMed]

56. Georgakilas, V.; Otyepka, M.; Bourlinos, A.B.; Chandra, V.; Kim, N.; Kemp, K.C.; Hobza, P.; Zboril, R.; Kim, K.S. Functionalization of graphene: Covalent and non-covalent approaches, derivatives and applications. Chem. Rev. 2012, 112, 6156-6214. [CrossRef] [PubMed]

57. Jiang, G.D.; Lin, Z.F.; Chen, C.; Zhu, L.H.; Chang, Q.; Wang, N.; Wei, W.; Tang, H. TiO 2 nanoparticles assembled on graphene oxide nanosheets with high photocatalytic activity for removal of pollutants. Carbon 2011, 49, 2693-2701. [CrossRef]

58. Gouttebaron, R.; Cornelissen, D.; Snyders, R.; Dauchot, J.P.; Wautelet, M.; Hecq, M. XPS study of TiOx thin films prepared by d.c. magnetron sputtering in Ar- $\mathrm{O}_{2}$ gas mixtures. Surf. Interface Anal. 2000, 30, 527-530. [CrossRef]

59. Girolami, G.S.; Jensen, J.A.; Pollina, D.M.; Williams, W.S.; Kaloyeros, A.E.; Allocca, C.M. Organometallic route to the chemical vapor deposition of titanium carbide films at excertionally low temperatures. J. Am. Chem. Soc. 1987, 109, 1579-1580. [CrossRef]

60. Gao, Y.; Pu, X.; Zhang, D.; Ding, G.; Shao, X.; Ma, J. Combustion synthesis of graphene oxide- $\mathrm{TiO}_{2}$ hybrid materials for photodegradation of methyl orange. Carbon 2012, 50, 4093-4101. [CrossRef]

61. Lai, Q.; Zhu, S.; Luo, X.; Zou, M.; Huang, S. Ultraviolet-visible spectroscopy of graphene oxides. AIP Adv. 2012, 2, 032146. [CrossRef]

62. Wong, C.P.P.; Lai, C.W.; Lee, K.M.; Abd Hamid, S.B. Advanced chemical reduction of reduced graphene oxide and its photocatalytic activity in degrading reactive black 5. Materials 2015, 8, 7118-7128. [CrossRef] [PubMed]

63. Saxena, S.; Tyson, T.A.; Shukla, S.; Negusse, E.; Chen, H.; Bai, J. Investigation of structural and electronic properties of graphene oxide. Appl. Phys. Lett. 2011, 95, 013104. [CrossRef]

64. Kumar, P.V.; Bardhan, N.M.; Tongay, S.; Wu, J.; Belcher, A.M.; Grossman, J.C. Scalable enhancement of graphene oxide properties by thermally driven phase transformation. Nat. Chem. 2016, 6, 151-158. [CrossRef] [PubMed]

65. Lu, Z.; Chen, G.; Hao, W.; Sun, G.; Li, Z. Mechanism of UV-assisted $\mathrm{TiO}_{2}$ /reduced graphene oxide composites with variable photodegradation of methyl orange. RSC Adv. 2015, 5, 72916-72922. [CrossRef]

66. Trusovas, R.; Račiukaitis, G.; Niaura, G.; Barkauskas, J.; Valušis, G.; Pauliukaite, R. Recent advances in laser utilization in the chemical modification of graphene oxide and its applications. Adv. Opt. Mater. 2016, 4, 37-65. [CrossRef]

67. Lin, Z.; Yao, Y.; Li, Z.; Liu, Y.; Li, Z.; Wong, C.-P. Solvent-assisted thermal reduction of graphite oxide. J. Phys. Chem. C 2010, 114, 14819-14825. [CrossRef]

68. Pan, X.; Yi, Z. Graphene oxide regulated tin oxide nanostructures: Engineering composition, morphology, band structure, and photocatalytic properties. ACS Appl. Mater. Interface 2015, 7, 27167-27175. [CrossRef] [PubMed]

69. Gurunathan, S.; Han, J.W.; Eppakayalla, V.; Kim, J.-H. Grenn synthesis of graphene and its cytotoxic effects in human breast cancer cells. Int. J. Nanomed. 2013, 8, 1015-1027. [CrossRef] [PubMed]

(C) 2018 by the authors. Licensee MDPI, Basel, Switzerland. This article is an open access article distributed under the terms and conditions of the Creative Commons Attribution (CC BY) license (http://creativecommons.org/licenses/by/4.0/). 